\title{
Determinants of Corporate Environmental and Social Disclosures in China: A Comparative Study within High-profile Industries
}

\author{
Junru Zhang \\ School of Business and Law \\ Edith Cowan University \\ Australia \\ Hadrian Geri Djajadikerta \\ School of Business and Law \\ Edith Cowan University
}

Australia

Terri Trireksani

School of Business and Governance

Murdoch University

Australia

Received: Feb. 12, 2018 Accepted: June 4, 2018 Published: June 4, 2018

doi:10.5296/ajfa.v10i1.12658 URL: https://doi.org/10.5296/ajfa.v10i1.12658

\begin{abstract}
This study examines the extent of environmental and social disclosures in annual reports made by Chinese mining, utility and chemical industries. It also investigates the key drivers of the companies' environmental and social disclosures (CESD), thereby determining the motivations of the sample organisations towards corporate environmental and social responsibility. The study adopted dichotomous index to measure the extent of CESD among the three industries in their annual reports. Additionally, Ordinary Least Square was adopted to examine the determinants of CESD. By drawing on legitimacy theory, the results depict positive associations between the extent of CESD and firm size, profitability, and firm age.
\end{abstract}




\section{Macrothink}

Asian Journal of Finance \& Accounting

ISSN 1946-052X 2018, Vol. 10, No. 1

Engagement from industry association showed strong significance in environmental disclosure, whereas leverage was significant in social disclosures. Government ownership was found insignificant in the analysis. The study contributes with direct evidence to the extent of environmental disclosure and social disclosure made by three high-profile industries based on G3. The results showed that overall there is no significant difference between the extents of CESD of the three industries, indicating that high-profile industries behave similarly in terms of the content of information in disclosure. This study has also practical implications particularly for the regulatory body and the industry association when developing regulations and guidelines on environmental and social reports.

Keywords: CESD, CSR, high-profile industry, Legitimacy Theory, China 


\section{Introduction}

China's economy has grown rapidly, at a rate of about $10 \%$ per annum in the past 30 years (China State Statistical Bureau, 2006), yet the severe impacts of this expansion on the social and natural environment have received insufficient attention. Up until now, Chinese firms' pursuit of profitability in sensitive industries (i.e. industries that are more likely to do environmental damage) has increasingly caused severe environmental and social problems. Mining, utility and chemical industries were specified and highlighted to be highly sensitive by the China State Statistical Bureau and the China Electricity Council (China State Statistical Bureau, 2006; "China electricity information", n.d.). Because of the industrial operation processes, in these industries a substantial deleterious environmental impact has been caused in China, where water pollution was highlighted to be one of the most intractable issues (Chen, 2010). Chen (2010) stated that the seven water systems are in emergency, and protection of the Yellow River urgently needs "Green GDP" responsibility. Poor food product quality, poor production safety facilities, and major health and occupational accident incidents were also revealed by the news media, and identified by researchers as the consequences of the organisations' pursuit of profit maximisation (Chu, 2007; Guo, 2005; Niu, 2009).

In this context, organisations, having the most active role in the market economy, cannot confine their attention to economic goals only, but must focus on a more extended qualitative approach and pay attention to their environmental and social responsibility through internal and external reporting (Guthrie \& Farneti, 2008). According to the definition, environmental and social responsibility reporting assists society to evaluate how well an organisation is performing with respect organisation's economic and social responsibilities (Lewiset al., 1995). However, in China, there are limited legislative accounting standards and legislative requirements for reporting corporate environmental and social information. Although a subset of listed firms reporting social responsibility by mandatory requirement (Chen et al., 2018), vast majority firms are in the absence of mandatory environmental and social reporting requirements. In 2006 and 2008, the Shenzhen and Shanghai Stock Exchange (SZSE and SSE) issued the 'Listed Corporate Social Responsibility (CSR) Guidelines', which have been formulated in accordance with the company law and securities law. This subsequently sets mandatory requirement for reporting CSR information to the firms in SSE 100 index, SSE Corporate Governance firms, and firms listed in foreign markets. While these guidelines instruct and require listed companies to actively fulfil regular assessment of their social and environmental responsibilities, their guidelines are typically generally do not provide specific indication as to what to disclose.

On the other hand, public awareness and concerns over environmental and social issues have been highlighted by the media, leading to an urgent need for additional corporate environmental and social disclosures. Although more firms are making corporate social and environmental disclosures, the level of disclosure is still inadequate (Guo, 2005; Liuet al., 2010), especially in aspects of comprehensiveness and consistency, thus hindering appropriate analysis (Chu, 2007). In this context, social and environmental disclosures have generated considerably significant issues in the business community and growing awareness 
of these disclosures have encouraged researchers to examine the disclosure information and its determinants (Chu, 2007; Dai \& Dong, 2010; Guan \& Yu, 2009; Kong, 1996; Peng, 2009).

Given this background, this study examines the extent of environmental and social disclosures in 2010annual reports made by Chinese mining, utility and chemical industries. It will also investigate the key drivers of the companies' environmental and social disclosures and compare the results between each sensitive industry, thereby determining the motivations of the sample organisations towards corporate environmental and social responsibility. The study contributes with direct evidence to the extent of environmental disclosure and social disclosure made by three high-profile industries based on GRI(G3). The results showed that overall there is no significant difference between the extent of corporate environmental and social disclosures (CESD) among the sample, indicating that high-profile industries behave similarly in terms of the content of information in disclosure. The result confirms the finding from prior literature one the treatment of sensitive industries as one group (Clarkson et al., 2008; Ong et al., 2016). In addition, the study also contributes to methodology for CESD measures, where environmental disclosure and social disclosure were measured independently. The analysis showed some difference among the drivers for the measures, even though both dimensions are considered as part of corporate sustainability development. The study indicates that government-ownership is not a strong factor promoting environmental disclosure and social disclosure, and high-profile companies were driven mostly by firm size, years become listed and profitability, which is consistent with the literature (Khan et al., 2013; Li \& Zhang, 2010; Ghazali, 2007). It is also interesting that the study found engagement from industry unions and associations are strong influence on environmental disclosures but to a much lesser extent to social disclosures. Overall, the three industries showed similar determinants of CESD, indicating that their behaviours did not differ significantly.

\section{Literature review and hypotheses development}

\subsection{CSED regulatory background}

Corporate social and environmental disclosing systems are influenced by both national and local regulations and standards. The disclosing system started with the 1972 United Nations Conference on the Human Environmental in Stockholm, which later led China's first National Environmental Protection Conference (Lin, 2008). Environmental Protection Offices were then established in 1974 and it pronounced the first the PRC's environmental regulation. The Chinese corporate environmental and social reporting and provisions, which are subjected to the Constitution of the People's Republic of China (PRC), consist of laws, provisions, regulations, ministerial and local regulations based on the Environmental Protection Act of the PRC (Guo, 2005). Lin (2008) found that there are implicit corporate social responsibility (CSR) disclosure obligations in the annual report under the current regulations - the regulation on the contents and Formats of the Annual Report (the Annual Reporting Regulation)" (Lin, 2008). The 2006 Company Law requires listed companies to consider environmental and social responsibilities in business operations.

The Code Corporate Governance for Listed Companies in China was also promulgated in 
2002, and it addresses that a listed company shall consider in the perspectives of the interest of banks, other creditors, employees, consumers, supplies, communities and other stakeholders. A number of sections and items from the Code require companies to disclosure relevant information regarding stakeholders, such as Article 28, 30 and section 8, which require directors to disclose in the manner of the interests of stakeholder concerning companies' sustainability issues, and for those companies that do not disclose, appropriate explanations for not disclosing are required to be given. It seems that under the current Chinese regulations, listed companies are required to undertake corporate social responsibility and consider the extent of their social and environmental performance in business operations. However, these regulations do not give specific list of guidelines on what to disclose and how to put it into practice. Therefore, the current regulations are not adequate. Although these articles require a range of information that directors should disclose, there are no specific indicators and sectors from the laws regarding environmental and social information. This suggests that corporate social and environmental disclosure (CESD) benefits stakeholders to a great extent but disclosures are not essentially mandatory. It concludes that corporate environmental and social reporting still remains voluntary for vast majority firms in the Chinese disclosure system.

\subsection{Corporate responsibility guidelines}

In 2006, one of the two central regions stock exchange markets in China, Shenzhen security exchange (SZSE) issued the Shenzhen Stock Exchange Guidelines on Corporate Social Responsibility (CSR) to acknowledge listed companies implementing social and environmental responsibility based on the laws, standards, regulations and rules (Wang et al., 2010). According to the SZSE guidelines, the publication is "based on the Company Law and the Securities Law with purposes of achieving scientific development, building harmonious society, advancing toward economic and social sustainable development, and promoting corporate social responsibility" (Shenzhen Stock Exchange Corporate Social Disclosure Guideline, n.d.). Although the SZSE guidelines were announced by the stock exchange market, applying them was under the supervision of the government. The basic framework of theSZSE guidelines is referred to as the GRI, which contain 8 chapters and 38 items that encourage the listed companies to commit to social accountability and promote sustainable economic and social development.

Since the SZSE guidelines on CSR were issued, the listed companies in the Shenzhen Stock Exchange have started to declare their CSR disclosure, and the guidelines are recognized as a standard measurement from many shareholders (Yuan, 2007). Existing studies suggest that the SZSE guidelines play an important role in improving the quality and quantity of corporate social disclosure. Chen (2010) explains that no companies were disclosing separate environmental and social reports or including CSR in an ordinary annual report before the SZSE guidelines became published. Yet in 2007, 20 listed companies issued their stand-alone reports and have referenced SZSE as their preferred guidelines. The guidelines issued from Shenzhen Stock Exchange Markets are voluntary initiatives and companies are not obliged to follow them. However, the standards have played an important role in guiding and monitoring the listed companies. Yin and Yu (2009) investigated the present status of the 
level of corporate social and environmental responsibility in all Chinese listed firms. They concluded that in the 2008 financial year, 32.5\% of the listed companies applied the SZSE guidelines for their social and environmental reporting (Yin \& Yu, 2009). The significance of the SZSE guidelines can be observed over the past years; however, they are not a suitable guideline for research purposes.

The SZSE guidelines were influenced by the Chinese government to a significant extent; however, they are not mandatory and still remain as an advocacy and suggestive reminders. Several researchers have pointed out that the SZSE guidelines do not provide the details of corporate environmental and social practices (Cheng \& Tan, 2008; Nie, 2009; Peng, 2009). For example, article 35 explains that "companies should establish the social responsibility mechanism as required by these instructions and work out social responsibility reports on a regular basis based on their review and evaluation of the status quo"; and article 33 indicates that "companies shall accept the supervision and inspection of the competent authorities and pay due regard to the public comments and media reports on themselves" (Shenzhen Stock Exchange Corporate Social Disclosure Guideline, n.d.). These items encourage companies to disclose; however, there is no specific information in these guidelines.

\subsection{Empirical studies in corporate social responsibility disclosures}

There has been increasingly large number of studies on corporate social responsibility (CSR) since early 2000, when developed nations started to promote CSR. Two main streams of research have been developed. The first stream includes studies on developing the measures and the instruments of corporate social responsibility, involving mainly the scale of CSR based on stakeholders' perception or from institutional demand (Lu \& Abeysekera, 2017; Chow \& Chen, 2012; Zhang et al., 2014; Ong et al., 2016). Another stream focuses on the drivers of CSR, including testing the relevance of CSR with firm performance (Zhu \& Zhang, 2015; Chen et al., 2018), corporate governance (Jo \& Harjoto, 2012; Flammer et al., 2017; Hubbard et al., 2017; Harjoto \& Jo, 2011), or ownership structures (Khan et al., 2013; Li \& Zhang 2010; Ghazali, 2007).

To define corporate environmental and social disclosures in the Chinese context, Lu \& Abeysekra (2015) developed a stakeholder-driven social and environmental index, which is examined among stakeholders, including shareholders, managers, creditors, regulators, HR managers, company employees, customers, suppliers, local community and media. The study indicated considerable difference in the perception of the stakeholders to corporate social responsibility based on the GRI criteria, in which stakeholder-oriented concept, such as labour and workplace treatment was perceived much importantly. Chow \& Chen (2012) found similar results that corporate managers are more likely to be driven by issues with high level of legitimation. In their study, environmental constructs were highly perceived due to the government engagement in environmental issue and companies' strategic choice of environmental sustainability. Both studies highlighted the importance of environmental and social constructs when investigation CSR. Later in 2016, Ong et al. (2016) extended the concept of hard disclosure and soft disclosure based on Clarkson et al. (2008). The study emphases the importance of including sustainability hard disclosure when developing a scale 
in content analysis for CESD. Hard sustainability disclosure refers to environmental performance indicator that is disclosed at the expense of the reporting firm, thereby hard to be mimetic by its peer firms (Clarkson et al., 2008). Ong et al. (2016) extend the concept from environmental aspect to other sustainability aspects, including governance, credibility, economic and social, and confirmed the values and the credibility of the hard sustainability disclosure items from GRI.

Prior literature confirms the scale on environmental and social items when measure CESD, as well as involving GRI in the valuation. This showed clear indication for measuring CESD for studies focusing on the drivers, particularly the Chinese studies which are not very much reviewed in the existing literature. An empirical study conducted by Yang (2009) adopted 208 small to medium firms in analysis using questionnaire. The questions reflected the firm's intensity of social responsibility towards employees and the public, in which the questions were grouped into firm specific factors and external factors, such as competitiveness of the market and the legal environment. The hypothesised variables were directly influenced by the questionnaire results. However, the external factors were not significant predictors of corporate social responsibility reporting. Yang (2009) found that the competitiveness of the market and the legal environmental condition were not perceived to influence corporate social responsibility disclosure at all. In contrast, the degree of social disclosures was strongly related to internal factors such as export intensity, innovation capability, management level, liquidity and financing capability.

Luo and $\mathrm{Wu}$ (2010) and Lianget al. (2011) used a similar approach to Yang (2009), where performance related factors were considered. Each variable was selected based on a number of prior research studies. Luo and Wu (2010) tested 336 sample companies listed on the Shenzhen and Shanghai Stock Exchange by analysing their 2006 annual reports. Factor analysis was used to construct a measure of CSD based on firms' ability to perform, growth, size and leverage factors. The authors considered that the influential factors behind CSD cannot be observed directly, but indirect associations can be found by analysing indirect indicators. In this case, a factor analysis was applied to reflect a high level of objectivity in the overall analysis. The authors found that CSD is predominantly related with corporate profitability and growth ability. Return on equity (ROE), return on asset (ROA) and earnings per share (EPS) were the key variables explaining CSD, as well as asset and sales growth. Firms are more likely to disclose, with higher intensity, in profitable companies. While firm size, growth capacity, core competencies and solvency also show a positive association with CSD; no significance was obtained.

In contrast, Liang et al. (2011) found that financial performance, company growth, asset quality and risk control were not influential to corporate social responsibility disclosure. They evaluated the quality of social responsibility from corporate standalone sustainability reports between 2005 and 2008 in 25 companies in banking industries. Contrary to Luo and Wu (2010), they adopted an unweighted index. The Global Reporting Initiative (G3) was used to identify disclosure items and indicators of the intensity of CSD. Subsequently, the voluntary social disclosures were considered under4 categories: social, customers, employees and stakeholders. The authors found that listed companies with large firm size had stronger levels 
of social responsibility. Disclosure quality also improves with the number of times a firm disclosed. They also found that stakeholders only pay little attention to CSD; the only relevant indicators were whether a company is listed. In other words, listed banks are often strictly required by the exchange markets to disclose social information.

Li (2006)examined the relationship between the level of a firms' social and environmental performance and the value of the sample 521 firms in year 2005, excluding financial companies listed in Shenzhen and Shanghai Stock Exchange market. The annual reports of each of the companies were collected to ascertain the level of CESD information. Li measured the categories of CESD by referring to the Chinese Corporate Governance Guidelines, such as responsibility to the environment, employees, local community, consumers and stakeholders. Tobin's Q value was used to measure the value of a firm. Li (2006) demonstrated that firm size (total assets), industry type and leverage were significant to the level of disclosure, but a negative correlation was found between the firm value and the level of CESD. With companies issuing ST shares, profitability was found to be significantly negative to CESD activities.

Yuan (2007) also examined the correlation between CESD and firm value, however, CESD was found to be positively related with firms with a higher value are more likely to provide better CESD quality. Yuan (2007) analysed the influential factors of disclosing firms' social and environmental responsibilities based on annual reports. The author used a set of relevant indicators and terms from the GRI, the Kinder, Lydenberg and Domini (KLD) 400 Social Index and the Dow Jones Sustainability Index. In this study, hypothesized variables were selected in aspects of firm specific factors, performance and governance. A multi-theoretical framework which were combined with stakeholder theory, information asymmetry theory, substitution theory and signal transfer theory, were adopted. The research compared 2005 annual reports, interim reports and quarterly reports for 291 listed companies in Shenzhen and Shanghai Stock Exchange, adopting the SZSE Guideline. It was found that large firms better performed in ROE were significant to the level of CESD. For those companies which disclosed social and environmental information with higher intensity, a significant association to the heavy pollution industries (manufacturing, mining and oil and gas companies) were also concluded.

Liuet al. (2009) used the same methodology as Yuan (2007) where Tobin's Q value was used to evaluate the value of a firm, and they tested the CESD in relation to firms' value. The authors also adopted stakeholder theory and ascertained performance and firm specific factors. The items were selected from the Shanghai Exchange Corporate Social and Environmental Disclosure Guidelines. Liu et al. (2009) found that large firms would be much more likely to disclose social information, and the intensity of disclosed social information had no influence to firm's value. The study comprised of a sample of 115 companies' annual reports for 2007 excluding firms from the financial and insurance industries listed in Shanghai Exchange.

Chu (2007) investigated the relationship between the implementation of firms' social responsibility and market performance in terms of 'contribution' expenses. Annual reports for 
2003, 2004, and 2005 were extracted from a sample of 123 industrial companies listed on Shanghai Stock Exchange. The population for this study was 156. Market performance was measured in 2004, 2005 and 2006 from China Stock Information database. Stakeholder theory and efficient capital market theory were adopted for selecting the variables. The author adopted the 'contribution rate' analysis in this study, where firms' expense on tax, dividends, employee wages, environmental protection, legal right and total contribution to the society were taken into account to measure the intensity of social responsibility. However, the author demonstrates that only the amount of total contribution to society has a significant positive relationship to firms' market performance. No association was found either from dividend expense or legal right. Therefore, the amount a firm spent on a series of social activities could not be fully explained to be significantly associated with CESD, which is not relevant to the firm value either.

Existing studies indicate that performance indicators(e.g. ROA and ROE) were the key drivers that influence both CSD and CESD. Firms within heavy polluting industries, including mining, manufacturing, oil and gas, and water and utility sectors, were shown to disclose more information (Luo \& Wu, 2010; Yuan, 2007; Li et al., 2009; Nie, 2009, Dai \& Dong, 2010, Liu et al., 2009; Peng, 2009; Song \& Zu, 2009). The large number of social and environmental criteria used to score CESD may at least partly explain these inconsistent results. These criteria included SZSE Corporate Social Disclosure Guidelines, SSE Social and Environmental Disclosure Guidelines, Chinese Corporate Governance Guidelines, KLD400 Social Index and GRI. Peng (2009), Nie (2009) and Liang et al. (2011) aimed to develop an appropriate frame in order to guide the companies to disclose social information to an acceptable level. On the other hand, Li(2006), Yuan (2007) and Liu et al. (2009) used the Tobin's Q value to determine firm value, and Nie (2009), Chu (2010) and Dai and Dong (2010) adopted the 'contribution' perspective, where the amount spent on each indicator disclosed in CESD was considered. Furthermore, studies of environmental and social disclosures that applied an unweighted index method were not shown to be using solely the GRI index.

This review of the literature highlights the increasing concerns from the stakeholders to CSD, and the close association between corporate characteristics and voluntary social and environmental disclosures. However, these existing Chinese studies have only been mainly based on stakeholder theory, and the results are inconsistent with various methods to measure the extent of CESD. Hence, there is a gap for adopting the legitimacy theory in order to determining the motivations of CESD. In addition, the extent of CESD was not measured by the dichotomous index under the G3 initiatives, neither was the GRI considered to be used solely. This study is designed to overcome the shortcomings from the previous studies in China. An unweighted index will be used under the G3 guidelines. As Chen (2010) stated, the Chinese corporations receive significant pressure from the government, which may be the reason that firms reporting social information to 'rescue' their legitimacy. Thus, the hypotheses development and variables are considered from the legitimacy theory approach. In addition, the sample of the study includes the sensitive industries, which are mining, utility and chemical companies. The extent of CSED is measured independent from two 
perspectives: corporate environmental disclosure and social disclosure.

\subsection{Legitimacy Theory}

From an organisational view, legitimacy is an operational resource that an organisation extracts from its society or cultural environment in order to pursue the goals. Legitimacy is a generalised perception or assumption that the actions of an entity are desirable, proper, or appropriate within some socially constructed system of norms, values, beliefs and definitions" (Suchman, 1995, p. 574). Suchman (1995) states that legitimacy is an operation resource that organizations extract from their cultural environments and that they employ in pursuit of their goals. Deegan (2002) defined that organisations continually seek to ensure that their activities are perceived by outside parties as 'legitimate'. They are social creations where "firms are recognised by performing various social actions" (Deegan, 2002, p. 292). Under this definition, the willingness of societal acceptance of organisations' continuing operation largely influences companies' social citizenship. Within the legitimacy theory, 'legitimacy' is considered as a fundamental resource on which an organisation is dependent for survival (O'Donovan, 2002). There are certain actions and events can increase legitimacy whereas some decrease it. Organisations having low legitimacy will have potentially negative consequences "which eventually lead to the forfeiture of their right to operate" (Tilling, 2004, p.4). However, the amount of legitimacy is often very subjective. Hybels (1995) argued that good models in the legitimacy theory must examine the relevant stakeholders. This is to ensure that how important the stakeholders influence the flow of business resources. Critical organisational stakeholders were identified by Hybels (1995), such as the state, the public, the financial community and the media. The importance of each stakeholder is different across nations due to cultural differences. Therefore, under this approach, the organisations are assumed to be influenced by their continuing operations, as well as the society where they operate.

An important reason the legitimacy theory is suitable is that, in China, an inseparable relationship between the state and its firms generates important social roles for the state-owned firms. This enables Chinese companies, particularly the state-owned companies, to have a tradition of taking social and environmental responsibilities (Li \&Wang, 1996). This legacy of the 'iron rice bowl' concept regarding lifetime employment and welfare persists (Song \& Zu, 2010), although a lesser degree can be observed in modern China. In addition, the managers in the state sector maybe often appointed by the Communist Party, subsequently, decisions made by the state-owned firms maybe amended by the Party leader. As a result, the management level of the appointed firms would always be the Communist Party members. Therefore, "they would naturally share their ideology with the state in favour of the communist tradition" (Song \& $\mathrm{Zu}, 2010$, p.106). Also, the mining, utility and chemical industries are the most sensitive industries, which are often exposed and concerned by the mass media and the public (Wang et al., 2010). According to O'Donovan (2002), repair legitimacy has been often related to crisis management. This suggests that companies in sensitive industries are more likely to be more "reactive, usually to an unforeseen and immediate environmental crisis" (O'Donovan, 2002, p. 344). In addition, to maintaining or gaining legitimacy, managements are required to "keep current" and be "proactive" with their 
social responsibility as the public requires over time (O'Donovan, 2002). In other words, CESD through annual reports can be explained as one of the effective communication tactics to implement legitimisation strategies (Lindblom, 1994). Therefore, the legitimacy theory predicts that companies issuing social and environmental disclosure will obtain, retain or repair legitimacy effectively.

\subsection{Government ownership (GOWN)}

State-owned firms receive close attention by the government and the public because these firms' operations and activities are often exposed and directly linked with the society and the media due to their perceived market power position and ownership structure ( $\mathrm{Li} \&$ Zhang, 2010). To avoid unfavourable news and influences, the management is more likely to disclose voluntary environmental and social information. Existing literature (Li \& Zhang, 2010) found positive association between government ownership and the extent of social and environmental disclosure that sample companies reported. Further, Kato \& Long (2006) indicated the structure of the government-ownership possess a strong connection with the pay towards social responsibility. Similarly, findings were confirmed by Situ et al. (2015), in which government engagement into ownership play vital role influencing the extent of environmental disclosure. Although the majority of the studies has considered the relationship between government-ownership and the extent of CESD, there is limited evidence to show the drivers within high-profiles industries linked with the extent of disclosure. Therefore, this study measures government ownership by a dummy variable to ' 1 ' if a firm has government-ownership, otherwise ' 0 '.

H1a: The extent of voluntary environmental disclosure in the annual reports of Chinese listed mining, utility and chemical companies is positively related to government ownership.

H1b: The extent of voluntary social disclosures in the annual reports of Chinese listed utility companies is positively related to government ownership.

\subsection{Management role (MNGR)}

More responsible managers are often assumed to provide better voluntary environmental and social disclosure. According to O'Donovan (2002), managerial intentions of using legitimisation strategies can vary among industries. In sensitive industries, companies are subjected to greater public exposure, thus management might elect maintain, gain or repair legitimacy through public disclosures (Hu, 2009). From the legitimacy theory perspective, these three strategies are in a sequence that reflects increasing difficulty for management and higher levels of required proactive involvement particularly in annual reporting (Deegan, 2009). This response is facilitated by the level of internal control that a high management role provides. However, management may adopt accounting policies that suit their personal benefit (Yuan, 2007). In this situation, rather than electing legitimacy, they may pursue short-term benefit, neglecting the enterprises' long-term sustainable benefit such as environment protection and employee welfare (Yuan, 2007). According to other studies, management role is measured by the proportion of independent directors over the total number of directors (Yuan, 2007; Nie, 2009). This study assumes that the higher the 
management role, the more likely a company would issue environmental and social disclosure (See Li, 2006; Yuan, 2007). Therefore, the following hypothesis is tested to determine the relationship between management role and the level of voluntary environmental and social disclosures. Management role rate is measured by the ratio between the number of independent directors and the total number of directors.

H2a: The extent of voluntary environmental disclosures in the annual reports of Chinese listed mining, utility and chemical companies is positively related to management role.

$H 2 b$ : The extent of voluntary social disclosures in the annual reports of Chinese listed mining, utility and chemical companies is positively related to management role.

\subsection{Member of industrial association (MIA)}

Due to the nature of social and environment sensitive work, there are a number of industrial associations established by the government for supervising and monitoring purposes. These companies are therefore more likely to face media exposure and political pressure from the government because they are directly monitored by the state. Under the legitimacy theory, those companies will be more likely to lose legitimacy which threatens their 'survivals' to a significant extent (Deegan, 2002). Previous studies have indicated that in China, the presence of being a member of a local industrial association would have a considerable impact to companies' behaviour implementing their social contract to the society where they operate (Li, 2006). To measure the association between the samples with industrial association, a dummy variable of ' 1 ' is used if a company is a member, other ' 0 '.

H3a: The extent of voluntary environmental disclosure in the annual reports of Chinese listed mining, utility and chemical companies is positively related to membership of an industrial association.

$H 3 b$ : The extent of voluntary social disclosure in the annual reports of Chinese listed mining, utility and chemical companies is positively related to membership of an industrial association.

\subsection{Profitability (PROF)}

The relationship between profitability and the level of environmental and social disclosure has been thoroughly discussed in existing literature (Liu et al., 2009; Yuan, 2007; Peng, 2009), where firms with higher financial performance are more likely to have a more advanced social disclosure. Legitimacy theory posits that companies are bound to an unwritten social contract within the society where they operate. Failure to comply with their legitimacy will threaten companies' performances and 'survival' (Deegan, 2002). In addition, Nie (2009) noted that positive news may facilitate investors' decision-making processes, and encourage them to build trust upon management. In return, this will reflect from management's compensation because a substantial increase in profit is shown to the shareholders, and so managers are more likely to disclose voluntary social information. Hence, it is not only in response to the 'resource' by the society where companies operate, higher profitable companies will be more likely to disclose voluntary environmental and social information. 
Return on assets (ROA) is used as a proxy to measure profitability.

H4a: The extent of voluntary environmental disclosure in the annual reports of Chinese listed mining, utility and chemical companies is positively related to profitability.

H4b: The extent of voluntary social disclosure in the annual reports of Chinese listed mining, utility and chemical companies is positively related to profitability.

\subsection{Operating leverage (LEV)}

There are a number of ways that companies may adapt in order to comply with social expectations and maintain or obtain legitimacy. Dowling and Pfeffer (1975) indicated that an organisation may consider altering the definition of social legitimacy through communication. Therefore, disclosing social and environmental information matches the organisation's practice, output and value. However, companies may have different capital structure, which creates conflicts to management to disclose or not.

Leverage ratio represents a company's ability to meet financial obligations, and can capture the importance of creditors as stakeholders in a firm's wealth (Ma \& Zhao, 2009). As creditors and financial institutions may share potential liabilities, they may demand information in order to meet their debt obligations. Potentially, there can be conflicts between disclosing social information and incentives of management. This is because from the shareholders' perspective, disclosure of social and environmental information may be perceived as a confession of guilt, so that they are reluctant to issue social disclosure in order to maintain their own value (Ma \& Zhao, 2009). According to Christopher and Filipovic (2008) and Ma and Zhao (2009) the higher the leverage, the more the company is likely to disclose social information. This also implies that if creditors are concerned with social responsibility activities, the company will be more likely to disclose environmental and social information. Leverage in this study is measured by debt to equity for operating leverage ratio.

H5a: The extent of voluntary environmental disclosure in the annual reports of Chinese listed mining, utility and chemical companies is positively related to operating leverage.

$H 5 b$ : The extent of voluntary social disclosure in the annual reports of Chinese listed mining, utility and chemical companies is positively related to operating leverage.

\subsection{Company age (AGE)}

Under the legitimacy theory, organisations' societal existence depends on the acceptance of the society where they operate. As the organisations can be influenced by, and have influences to the society, legitimacy is assumed as an important resource determining their survival (Deegan, 2002). Older companies with longer societal existence may have taken relatively more legitimacy. According to Yang (2009), these companies usually have longer performance experience and histories, and are mature. Subsequently, organisations' reputation and involvement of social responsibility may become ingrained (Kong, 1996). As a company operates longer, there will be more communication needed to the outside community. This provides companies with wide social networks, affecting their public images (Yang, 2009). In sensitive industries, the public and the media can be quickly alerted if a mature company 
reduces the extent of social activities. Consequently, it will result in company regulations and political pressure from the outside to encourage disclosing social responsibility and practices (Yuan, 2007). As voluntary social disclosure is a way that management can actively overcome this pressure from the public, the longer a company has been listed on the Stock Exchange, the more likely the company would disclose social information. Other studies have found positive significant relations between company age and the extent of voluntary social disclosure (Roberts, 1992; Yang, 2009). Company age in this study, therefore, is measured by the number of years a company has become listed.

H6a: The extent of voluntary environmental disclosure in the annual reports of Chinese listed mining, utility and chemical companies is positively related to company age.

H6b: The extent of voluntary social disclosure in the annual reports of Chinese listed mining, utility and chemical companies is positively related to company age.

\subsection{Firm size (SIZE)}

Large firms in sensitive industries are deemed to be more subjected to public exposure, and often they would face more legitimate issues than smaller firms (Watts \& Zimmerman, 1978). As a result, large firms can be easily subjected to "public expectation of social performance, government-imposed taxation and other regulations, as well as more media attention and exposure" (Hu, 2009, p. 53). Hence, larger firms are more likely to use certain accounting policies in order to enhance their legitimacy. In addition, under the legitimacy theory, large companies would be expected to comply with their 'social contact'. One effective way that they can present this, is by reporting environmental and social information through annual reports. Following the legitimacy theory, larger firms would have more incentive to disclose voluntary environmental and social information to manage their social contract and legitimacy.

H7a: The extent of voluntary environmental and social disclosure in the annual reports of Chinese listed mining companies is positively related to firm size.

$H 7 b$ : The extent of voluntary environmental and social disclosure in the annual reports of Chinese listed utility companies is positively related to firm size.

H7c: The extent of voluntary environmental and social disclosure in the annual reports of Chinese listed chemical companies is positively related to firm size.

In previous research, firm size has been mostly measured by total assets when legitimacy isof concerned (Dai \& Dong, 2010; Hu, 2009). To be consistent, this study uses total assets to represent firm size.

\section{Methods}

A sample of large high-profile listed companies in China were selected for hypothesis testing, which include the mining, utility and chemical industries. The listed Chinese companies started to report social responsibility to difference context due to the controls from regulatory bodies, as such companies by mandatory requirement were excluded from the samples. The 
total sample firms adopted in this study, thus, includes 47 mining firms, 73 utility firms and 73 chemical firms. In order to testify social and environmental disclosures in report, annual reports in 2010 were collected to examine the extent and the determinants of corporate social and environmental disclosures. In this study, the entire population in the listed mining and utility industries were employed, which were 50 and 75 respective. Additionally, a sample of 83 chemical companies was also selected for comparison of the legitimacy within the high-profile industries.

To examine the extent of corporate social and environmental disclosures, a dichotomous index (unweighted index) will be used in this study to score the sample companies against each of the GRI indicators. Alternative indices were previously used by researchers, such as the number of words or weighted index. However, this study is concerned with the extent of the corporate environmental and social disclosures as opposed to the company's importance on disclosed items. One advantage for using unweighted index is that it decreases and avoids the items being treated unequally, and minimises the risk of subjectivity created when measuring the actual quantity of environmental and social disclosure. For content analysis, a score of one for each indicator provided, and a score of zero for indicators not reported. The GRI environmental or social indicators were added independently to provide total scores for the extent of each environmental or social disclosure by the selected companies.

To testify the determinants of the extent of disclosures, Ordinary Least Square multi-regressions model is used to identify the contribution to the significance of each added independent variable and determining the key influential characterises. Prior to using the regression model, it is required to test the assumptions in order to ascertain they are true, for example normality and multicollinearity. A regression model is considered to provide better robust results because it examines the combined influence of all variables to explain their relations to corporate environmental disclosure and social disclosure, and how each variable influence disclosure (Coakeset al., 2010). According to Hairet al.(1995), multi-regression model evaluates the predictive power of explanatory variable objectively while improving the prediction of dependent variable. Thus, it demonstrates statistical significance to how each independent variable affects the extent of corporate environmental and social disclosure. Another reason for choosing this method is that the majority of independent variables are either ratio or continuous variables, whereas the dependent variables are additive and non-continuous (Mendenhallet al., 1988). The models tested are shown as follows:

Model 1

$\mathrm{CESD}_{\mathrm{Env}}=\beta_{0}+\beta_{1} G O W N+\beta_{2} M N G R+\beta_{3} M I A+\beta_{4} P R O F+\beta_{5} L E V+\beta_{6} A G E+\beta_{7} S I Z E+\varepsilon i$

$\underline{\text { Model } 2}$

$\operatorname{CESD}_{\text {social }}=\beta_{0}+\beta_{1} G O W N+\beta_{2} M N G R+\beta_{3} M I A+\beta_{4} P R O F+\beta_{5} L E V+\beta_{6} A G E+\beta_{7} S I Z E+\varepsilon i$ 


\section{Results}

\subsection{Level of environmental and social reporting}

The descriptive statistics that show the number of GRI disclosures and percentage of companies disclosing in China are presented in Table 1. Within the 193 sample annual reports were viewed in total, it is notable that many companies have disclosed only general and positive information. A few companies reported information specifically related to corporate environmental information. Mining companies have achieved an average of 2.68 disclosures per company, but utility and chemical companies experienced a substantial decrease of $9.7 \%$ and 32\% (2.42 and 1.82 disclosures per company). This result shows that the extent of environmental disclosure in the sample company is not generally high. The figure shows also that there are 30 disclosing items listed in the G3 and only less than $10 \%$ are being reported by these companies. Interestingly, there are equal amount of disclosing and non-disclosing companies in utility and chemical industries. Mining companies present the highest number of disclosing companies, with only 3 non-disclosing companies. In utility and chemical companies, the percentage in the number of disclosing companies drops by $16.27 \%$. The results from descriptive statistical overall shows that the extent of environmental disclosure is considerably similar for the three industries.

Note that the ranges of initiatives reported are kept constant from 1 to 10 in mining industry and 1 to 11 in utility and chemical industries. This suggests that there are some companies which choose to enhance their environmental reporting by following the GRI and achieved comparatively high scores of 10 and 11, although only 30 percent of the G3 disclosing items were reported. This again reflects the overall Chinese voluntary environmental disclosing level is typically low. 
Table 1. Descriptive statistics for environmental disclosures

\begin{tabular}{llll}
\hline & Mining industry & Utilityindustry & Chemical industry \\
\hline Mean & 2.68 & 2.42 & 1.82 \\
Standarddeviation & 2.406 & 2.345 & 1.888 \\
Range & $0-10$ & $0-11$ & $0-11$ \\
Non-disclosingcompanies & 3 & 13 & 13 \\
Disclosing companies & 44 & 60 & 60 \\
Non-disclosingcompanies in \% & $6.4 \%$ & $21.67 \%$ & $21.67 \%$ \\
Disclosing companiesin \% & $93.6 \%$ & $78.33 \%$ & $78.33 \%$ \\
Total number ofcompanies & 47 & 73 & 73 \\
\hline
\end{tabular}

For social disclosures, companies from all three industries participated to some extent of social disclosure, which means there was at least one item disclosed by the sample companies. Due to the entire sample companies have disclosed information included in these items, the disclosing rate remains high comparing with environmental disclosure. As Table 2 presents, utility industry has the highest mean value, where averages of 5.55 social GRI indicators were obtained from companies' annual reports. This is followed by the mining industry, then chemical industry, in which 5.49 and 4.96 disclosures were shown in annual reports.

These results show that the extent of social disclosure in the sample companies across industries is similar but remain typically low. This is because there are 40 disclosing items listed in the G3 social indicators and only on an average of 5.49 were disclosed in mining industry, 5.55 were disclosed in utility industry and 4.96 were disclosed in chemical industry. In addition, the range for social disclosures for all industries has a minimum of 4 and a maximum of 15 for mining industry, 14 for utility industry and 9 for chemical industry; however, the mean values are not much more than the minimum of their range. Therefore, the social reporting performances from sample industries are not high, and they remain approximately the same across industries. 
Table 2. Descriptive statistics for social disclosures

\begin{tabular}{llll}
\hline & Mining industry & Utilityindustry & Chemical industry \\
\hline Mean & 5.49 & 5.55 & 4.96 \\
Standard deviation & 1.921 & 2.028 & 1.086 \\
Range & $4-15$ & $4-14$ & $4-9$ \\
Non-disclosing companies & 0 & 0 & 0 \\
Disclosing companies & 47 & 73 & 73 \\
Non-disclosing companies in \% & $0 \%$ & $0 \%$ & $0 \%$ \\
Disclosing companies in \% & $100 \%$ & $100 \%$ & $100 \%$ \\
\hline Total number of companies & 47 & 73 & 73 \\
\hline
\end{tabular}

\subsection{The drivers of environmental disclosure}

The results from multiple regressions showed the models are statistically significant to mining, utility and chemical industries. Table 3 presents the standardised beta comparison across industries with the associated $p$ values. Interestingly, member of industrial association, company listing age and company size were found to be statistically significant among all industries. The independent variable, member of industrial association, influences utility industry the most with beta of 0.490 , following by chemical industry and mining industry with beta of 0.420 and 0.305 respectively. Company listing age and company size were also found to be significant, influencing the mining industry the most with betas of 0.156 and 0.461 , followed by utility industry and chemical industry with betas $0.141,0.270$ and 0.139 , 0.255 . Company profitability was found to be a key determinant in both mining and chemical industries, and it correlates mining industry with beta of 0.421 , whereas the beta for chemical industry is 0.171 . Although it does not show a significant $\mathrm{p}$ value for utility industry, the significance level approaches the moderate level. Moreover, leverage ratio is only found to be significant in utility industry, and the remaining variables (i.e. government ownership and management role) did not show any significant results. In summary, there is not much difference that the independent variables influence across industries.

It is interesting that government ownership and the independent director ratio were not shown to be significant in any of the sample industries; however, the overall results show that the three industries share a lot in common and they do have the same trend in predicting the extent of environmental disclosures by using the same independent variables. This indicates that it might be possible to have the three industries included in one single model instead of 
three different models.

Table 3. Results of multiple regressions (environmental disclosure)

\begin{tabular}{|c|c|c|c|c|c|}
\hline Variable & Hypothesis & Expected sign & Mining & Utility & Chemical \\
\hline GOWN & $\mathrm{H} 1$ & + & 0.110 & 0.124 & 0.058 \\
\hline MIA & H3 & + & $0.305^{* *}$ & $0.490 * * *$ & $0.420 * * *$ \\
\hline AGE & $\mathrm{H} 6$ & + & $0.156 * *$ & $0.141 * *$ & $0.139 *$ \\
\hline SIZE & $\mathrm{H} 7$ & + & $0.461 * * *$ & $0.270 * *$ & $0.255^{* *}$ \\
\hline PROF & $\mathrm{H} 4$ & + & $0.421 * * *$ & $0.157^{*}$ & $0.477^{* * *}$ \\
\hline LEV & H5 & + & 0.129 & $0.450 * * *$ & $0.176^{*}$ \\
\hline MNGR & $\mathrm{H} 2$ & + & $0.128^{*}$ & $0.159 *$ & 0.125 \\
\hline$R^{2}$ & & & 0.364 & 0.322 & 0.327 \\
\hline
\end{tabular}

Note: $\mathrm{N}_{\text {mining }}=47, \mathrm{~N}_{\text {Utility }}=73, \mathrm{~N}_{\text {Chemical }}=73$; R-square significant tests are based on $\mathrm{F}$ values; ${ }^{*} \mathrm{p}<0.1$; $* * \mathrm{p}<0.05 ; * * * \mathrm{p}<0.01$, two-tailed coefficient test

\subsection{The drivers of social disclosure}

The models of social disclosure also showed statistical significance among mining, utility and chemical industries. Table 4 shows that the sample industries share much in common based on the legitimacy theory and they are found to be considerably similar. SIZE is found to be significant in both the mining industry and utility industry, and the extent of PROF's influences is similar; they have betas of 0.565 and 0.503 respectively. Although it was found to be insignificant in chemical industry, the $\mathrm{p}$ value of SIZE approached the moderate significance level with a beta of 0.315 . Variable SIZE was found to be significant in all sample industries. It is most significant that the chemical companies had a beta of 0.504 . SIZE influences to a lesser extent than in the other two industries, where the betas are 0.495 and 0.413 . In addition, MNGR of the chemical industry similarly has the highest value of beta; this was shown to be statistically significant. The mining industry and utility industry, had betas of 0.423 and 0.393 . For variable LEV, mining and utility industries had moderate significance levels, and it influences mining industry with beta of 0.437 . Utility was influenced the most with a beta value of 0.447 . Since this variable was transformed back to $\mathrm{LEV}$, it is no longer significant to chemical industry. AGE was only found to be significant in chemical industry, and the remaining sample industries sampled were found to have largely insignificant levels, approaching moderate significance level at best. 
Interestingly, GOWN and MIA were found to be insignificant in all three industries; however, the $\mathrm{p}$ values approach moderate significance level and their signs meet the expected signs directions. The overall comparison indicates that the empirical evidence shows most of the hypothesised variables are able to explain the extent of social disclosure in Chinese mining, utility, and chemical companies. There are four independent variables, SIZE, PROF, LEV and MNGR, which the sample companies have in common, indicate whether they influence and determine the extent of social disclosure. Moreover, GOWN and MIA were found to be insignificant in all industries while approaching moderate significance level. Therefore, the results reveal that overall, the three industries were determined by the same variables, and that it may be possible to have the three industries included in one model instead of three.

Table 4. Results of multiple regressions (social disclosure)

\begin{tabular}{|c|c|c|c|c|c|}
\hline Variable & Hypothesis & Expected sign & Mining & Utility & Chemical \\
\hline GOWN & $\mathrm{H} 1$ & + & $0.312^{*}$ & $0.189 *$ & $0.149 *$ \\
\hline MIA & $\mathrm{H} 3$ & + & $0.395^{*}$ & $0.285^{*}$ & 0.126 \\
\hline AGE & $\mathrm{H} 6$ & + & $0.388^{*}$ & 0.155 & $0.317 * *$ \\
\hline LnSIZE & $\mathrm{H} 7$ & + & $0.495 * *$ & $0.413 * *$ & $0.504^{* * *}$ \\
\hline RecPROF & $\mathrm{H} 4$ & + & $0.465^{* * *}$ & $0.503 * * *$ & $0.315^{*}$ \\
\hline LEV & H5 & + & $0.437^{*}$ & $0.447 * *$ & $0.299 * *$ \\
\hline MNGR & $\mathrm{H} 2$ & + & $0.423 * *$ & $0.393 * *$ & $0.513 * * *$ \\
\hline$R^{2}$ & & & 0.381 & 0.329 & 0.392 \\
\hline
\end{tabular}

Note: $\mathrm{N}_{\text {mining }}=47, \mathrm{~N}_{\text {Utility }}=73, \mathrm{~N}_{\text {Chemical }}=73$; R-square significant tests are based on $\mathrm{F}$ values; $* \mathrm{p}<0.1 ; * *_{\mathrm{p}}<0.05 ; * * \mathrm{p}<0.01$, two-tailed coefficient test

\section{Discussion and findings}

The results from this study indicate that certain variables from the legitimacy theory are able to explain the extent of voluntary environmental disclosures in Chinese mining, utility and chemical companies' annual reports, whilst other variables are less able to.In terms of the results for environmental disclosures, this study shows the applicability and predictive power of the legitimacy theory by having more than half of the predicting variables being statistically significant. First, companies that are more profitable (in terms of ROA), disclose significantly more than the others that are less profitable. Although this hypothesis shows a moderate significance in electricity companies, it is still statistically significant. This corresponds with the legitimacy theory that suggests older, larger and profitable companies 
face more media exposure, which can threaten their survivals. In the circumstance, they obtain social acceptance or reputation for being the societal citizen through environmental disclosures. It indicates that while these companies are able to remain profitable, they are also capable of implementing corporate environmental responsibility. Moreover, companies that have become a member of industrial associations established by the government disclose significantly more environmental information in their annual reports than the other ones across the three sample industries.

Due to the natural environmental sensitive business activities, Chinese industrial associations have set policies for companies to implement environmental responsibilities in accordance with the national sustainability plans. Companies that do not disclose the required amount of information are more likely to experience legitimacy loss through industrial media exposure. As explained by the legitimacy theory, a considerable impact to companies' social contract can influence their survival significantly (O'Donovan, 2002); therefore, companies are willing to disclose more information. In addition, the results show that these associations have played extraordinarily well in terms of supervising and monitoring. According to the $10^{\text {th }}$ five-year plan, the Chinese government announced to reduce pollution emissions by $10 \%$ but it did not meet the target by the end. The objective to reduce emissions by another $10 \%$ has been set in the $11^{\text {th }}$ five-year plan (valid from 2006 to 2010 ), and $14.29 \%$ for the $12^{\text {th }}$ five year plan. These plans have been incorporated by the industrial associations in order to improving the current status of corporate environmental performance in China. However, plans are not mandatory regulations and rules, and having the plans cannot increase the overall environmental disclosure after all. Another reason could be the Five Years Sustainable Plan, where information regarding companies' use of material, energy consumption and general performance on environment is encouraged in annual reports. Nonetheless, disclosure is on a voluntary basis; some companies choose to follow the advice while some do not. In addition, as suggested by the legitimacy theory, environment-sensitive industries are more likely to face legitimacy issues and directors in those companies are more likely to disclose relevant information in order to promote or rescue companies' social acceptance. This could be the reason that mining companies disclose more information than the other two industries. The China Electricity Council has indicated that the Chinese mining industry has become increasingly concerned nationally about its environmental performances. It is ranked as the top environmentally concerned industry by Chinese industrial association, and is also sensitive to the public's concern about its matter.

By looking at the results from mining industry, multivariate analysis shows that membership of industrial association and profitability are highly correlated and therefore are able to explain the extent of environmental reporting. Hypotheses three and four are accepted. Company listing age and company size were found to be moderately significant, whereas government ownership, leverage and the ratio of independent directors were found to be insignificant. In Chinese utility industry, the extent of environmental disclosures can be determined by variables member of industrial association, company listing age and leverage ratio according to the multivariate results. Therefore, hypotheses three, five and seven are accepted, the other four variables, government ownership, company size, profitability and 
management role are less significant. Company size is found to be moderately significant, whereas leverage ratio and the number of independent directors were less significant, approaching moderate significance level. Government ownership is found not to be significant. For chemical industry, hypotheses three and four are accepted and the remaining five hypotheses, government ownership, company age, company size, leverage and management role are rejected. Company listing age and company size were found to be moderate significant. Leverage ratio is less moderate significant, whereas government ownership and number of independent directors are not significant.

The overall results show that there are four common variables that are positively significant in all industries: member of industrial association, company age, company size and profitability, which is consistent with the existing literature (see Chen et al., 2018; Oh et al., 2011; Kang, 2013; Cai et al., 2011; Gomez-Mejia et al., 2003). The variable management role approaches moderate significance in mining and utility industry, with operating leverage approaching moderate significance in the chemical industry, and significant correlation can be observed in utility industry. The remaining variables (government ownership, leverage and management role) were found to be insignificant in all industries.

\section{Concluding remarks}

The study provides evidence to the drivers of environmental and social disclosures made by mining, utility and chemical companies in China. The results indicate that the MIA was found to have a strong significant relation to the extent of environmental disclosures, which is consistent with prior literature (Song \& $\mathrm{Zu}, 2009$ ). The inference is that the local industrial associations in China, such as Chinese Mining Federation, Chinese Electricity Council and Chinese Chemical Industrial Association, played important roles, encouraging corporate boards and managements to voluntarily disclose environmental information; however, the descriptive statistics provide evidence that there were only 2.68 indicators per mining company, 2.42 indicators per utility company and 1.82 per chemical company. This suggests that the disclosure manner for the sample companies can be influenced effectively by industrial associations if they are the members, but the encouragement for disclosing a wide range with detailed information regarding environmental information was not sufficient.

The implication is that the industrial association, more likely the government, will need to consider the prescription of the GRI as a reference when preparing environmental disclosures, and make it into the relevant guidelines. The significance across the three industries showed that the industrial associations in China have the identical amount of influence across industries.However, MIA has limited influences on the social aspect, and the encouragement for corporate management is not effective; hence, it is clear that disclosures of social performances appears to be not very much required and instructed by the government and its agencies alike.

In addition, profitability and leverage were shown significance in mining and chemical industries, with weaker significant relationships in utility firms. Company sizeand company age were found to have moderate significant relationship across industries. These variables, again, demonstrate that the sample industries have the similardrivers in terms of corporate 
financial features. This suggests that corporate with financial features in common tend to disclosure the same amount of environmental information in quantity. The implication is that economic features and activities that add value to companies are important factors that motivate corporate managements to disclose environmental information voluntarily. This further implicates that it is important for the government to link financial incentives with environmental information reporting, such as having subsidiaries for corporate pollution control. This will motivate the managements voluntarily disclose environmental information.

Interestingly, government ownership was found insignificant in the sample industries. This suggests that the management of Chinese listed mining, utility and chemical companies were not motivated by the companies being stated-owned. As China develops, there has been increasing emergence of private sectors ownership in the last few decades, and whether a company is state-owned is no longer a strong motivation for the management to voluntarily disclose environmental information (Chen et al., 2018; Taylor \& Shan, 2007). In order to increase the extent of environmental disclosure in China, the government need to have a set of detailed and adequate environmental reporting guidelines with precise instructions as a part of mandatory requirement.Company age was also found to have weak significant relationship across industries. Older companies operate longer and would need more communication to the outside community; however, the results suggest that the influences of their wide social networks and public images do not motivate much the managements to disclosure social information. The implication is that the corporate managements are not concerned with the social public image based on their company age.

This study extended the current research on social and environmental disclosure to the context of China. The findings on environmental and social disclosure analysis can contribute to the development and policy making among high-profile companies. The Chinese officials have been implementing environmental and social responsibility controls after 2008; however, it has been highlighted by prior studies that ambiguity and uncertainty within the regulations and guidelines has led companies' report difficult to compare among other firms (Lu \& Abeysekera, 2017). The findings of this study indicate that environmental sensitive firms (mining, utility and chemical) disclose considerably similar information, and it shows insights in revising the existing and future governmental regulations and guidelines to treat the three subsets as one group. Additional research can be taken to relating to seek for improving the quality of disclosures, especially through controlling external assurance process, which is currently at infant level in the Chinese context.

In addition, this study also makes methodological contribution to environmental disclosure and social disclosure measures, in which the two dimensions were treated independently. The findings indicate that environment disclosure and social disclosure are driven differently, even though the majority of the significant variables are similar. Overall, these are two dimensions under corporate sustainability and they shall be treated as one group when investigating corporate sustainability development. However, the study must consider several limitations. First, due to the changing and complex nature of the business environment, there can be inherent difficulties and restrictions to capture corporate environmental and social responsibility in a single period observation. Hence, the results do not show the trend of 
development of corporate environmental and social disclosure over several years. Future studies can apply a longitudinal method, whereby companies' annual reports from a number of years can be selected. Annual reports are not the only source that companies disclose environmental and social information with. Companies that have disclosed through stand-alone reports, web-site disclosure or media announcement may have less or none environmental or social information in annual reports. Also, there is a limitation for using dummy variables as proxies for 'government ownership' and 'management role' in the multiple regression models. Dummy variable is effective and useful for testing categorical factors and their relationships between predictors and responsible variables. However, using dummy variable is a non-parametric approach which does not assume form for functional relationship (Cohen, 1991). Therefore, regressions included dummies often lose functional form of relationship and the slop of the regressions are most like to be influenced. Nonetheless, dummy variables are most commonly used by researchers in multiple regressions because the extent that they influence the slope is negligible. Finally, this study focuses solely on the quantitative approach and hence a dichotomous index was employed to identify the extent of companies' environmental and social disclosures. The limitation of this method is that all items are being treated as equally important. Future research can overcome this by analysing both quantitative and qualitative approaches. For example, weighted index measures can be used to examine the level of importance of each GRI item of disclosure. In conclusion, this study extends and contributes to the existing studies on corporate environmental and social disclosures in China by providing evaluation and measures the type and extent of company environmental and social disclosures solely using the Global Reporting Initiative (G3) as a benchmark among the most sensitive industries.

\section{References}

Cai, Y., Jo, H., \& Pan, C. (2011). Vice or virtue? The impact of corporate social responsibility on executive compensation. Journal of Business Ethics, 104(2), 159-173. https://doi.org/10.1007/s10551-011-0909-7

Chen, W. (2010). Lun qi ye she hui ze ren xin xi pi lu ying xian yin su [Research on the factors influencing corporate social disclosure]. Cai Jing Li Lun Yu Shi Jian31(166), 96-100.

Chen, Y. C., Hung, M., \& Wang, Y. (2018). The effect of mandatory CSR disclosure on firm profitability and social externalities: Evidence from China. Journal of Accounting and Economics, 65(1), 169-190. https://doi.org/10.1016/j.jacceco.2017.11.009

Cheng, Y. M., \& Tan, Y. (2008). Wo guo she hui ze ren kuai ji xin xi pi lu ti xi tan xi [Social accounting system analysis]. Qi Ye Cai Wu Guan Li, 378-383

China electricity information. [n.d.]. Retrieved June 2011, from http://www.chinapower.com.cn/newsarticle/1099/new1099753.asp.

China State Statistical Bureau. (2006). China Statistical Abstract for 2006. China Statistical Press, Beijing.

Christopher, T., \& Filipovic, M. (2008). The extent and determinants of disclosure of Global 
Reporting Initiative Guidelines: Australian evidence, The Journal of Contemporary Issue in Business and Government, 14(2), 17-40.

Chow, W. S., \& Chen, Y. (2012). Corporate sustainable development: testing a new scale based on the mainland Chinese context. Journal of Business Ethics105(4), 519-533. https://doi.org/10.1108/sd.2012.05628gaa.010

Chu, X. (2007). Empirical study on the relation between taking society responsibility and market performance of listed company - take the Shanghai industrial enterprise as the example (Unpublished master's dissertation), Xinjiang University of Finance.

Clarkson, P. M., Li, Y., Richardson, G. D., \& Vasvari, F. P. (2008). Revisiting the relation between environmental performance and environmental disclosure: an empirical analysis. Accounting, Organisations and Society, 33, 303-327. https://doi.org/10.1016/j.aos.2007.05.003

Coakes, S. J., Steed, L., \& Ong, C. (2010). SPSS: analysis without anguish: version 17 for Windows. John Wiley \& Sons Australia, Ltd, Milton, Qld.

Cohen, A. (1991). Dummy variables in stepwise regression. The American Statistician, 45(3), 226-228.

Dai, F. J., \& Dong, S. L. (2010). Shang shi gong si she hui ze ren kuai ji xin xi pi lu ying xiang yin su yan jiu [Corporate social disclosure on accounting information]. Cai Kuai Tong Xun,12, 75-78.

Deegan, C. (2002). The legitimising effect of social and environmental disclosures - a theoretical foundation. Accounting, Auditing and Accountability Journal, 15(3), 282-311. https://doi.org/10.1108/09513570210435852

Deegan, C. (2009). Financial accounting theory. McGraw-Hill Australia, Sydney.

Dowling, J., \& Pfeffer, J. (1975). Organizational legitimacy: social values and organisational behaviour. Pacific Sociological Review, 18(1), 122-136. https://doi.org/10.2307/1388226

Flammer, C., Hong, B., \& Minor, D. (2017). Corporate governance and the rise of integrating corporate social responsibility criteria in executive compensation. https://doi.org/10.2139/ssrn.2831694

Ghazali, N. (2007). Ownership structure and corporate social responsibility disclosure: some Malaysian evidence. Corporate Governance, 7(3), 251-266. https://doi.org/10.1108/14720700710756535

Gomez-Mejia, L. R., Larraza-Kintana, M., \& Makri, M. (2003). The determinants of executive compensation in family-controlled public corporations. Academy of Management Journal, 46(2), 226-237.

Guan, Z., \& Yu, Z. H. (2009). A Study of China's Corporate Social Responsibility Reports. WTO Economics Guide, 151-107. 
Guo, P. (2005). Corporate environmental reporting and disclosure in China (Unpublished doctoral dissertation), Tsinghua University, Beijing.

Guthrie, J., \& Farneti, F. (2008). GRI sustainability reporting by Australian public sector organisations. Public Money and Management, 28(6), 361-366. https://doi.org/10.1111/j.1467-9302.2008.00670.x

Hair, J. F., Anderson, R. E., Tatham, R. L.,\&Black, W. C. (1995).Multivariate data analysis with readings.America: Prentice-Hall, Inc., New Jersey.

Harjoto. M. A.,\&Jo, H. (2011). Corporate governance and CSR nexus. Journal of Business Ethics, 100, 45-67. https://doi.org/10.1007/s10551-011-0772-6

$\mathrm{Hu}$, J. (2009). The impact of Beijing Olympic sponsorship program on annual report social disclosure by local sponsors (Unpublished honours dissertation), Edith Cowan University.

Hubbard, T. D., Christensen, D. M.,\& Graffin, S. D. (2017). Higher highs and lower lows: The role of corporate social responsibility in CEO dismissal. Strategic Management Journal, 38(11), 2255-2265. https://doi.org/10.1002/smj.2646

Hybels, R. C. (1995). On Legitimacy, Legitimation and organisations: A critical review and integrative theoretical model. Academy of Management Proceedings, 241-245. https://doi.org/10.5465/ambpp.1995.17536509

Jo, H., \& Harjoto, M. A. (2012). The causal effect of corporate governance on corporate social responsibility. Journal of Business Ethics, 106, 53-72. https://doi.org/10.1007/s10551-011-1052-1

Kang, J. (2013). The relationship between corporate diversification and corporate social performance. Strategic Management Journal, 34(1), 94-109. https://doi.org/10.1002/smj.2005

Kato, T., \& Long, C. (2006). Executive turnover and firm performance in China. American Economic Review, 96(2), 363-367. https://doi.org/10.1257/000282806777212576

Khan, A., Muttakin, M. B., \& Siddiqui, J. (2013). Corporate governance and corporate social responsibility disclosures: evidence from an emerging economy. Journal of Business Ethics, 114(2), 207-223. https://doi.org/10.1007/s10551-012-1336-0

Kong, G. S. (1996). Social disclosure by Australianlisted mineral mining companies: a stakeholder approach (Unpublished master's dissertation), Edith Cowan University, Joondalup, W.A.

Lewis, N.R., Mangos, N.C., \& Tilt, C. (1995). A review of environmental accounting: issues for Australian accountants, corporations and regulators. Australian Society of Certified Practising Accountants' Public Sector Accounting Centre of Excellence, Melbourne.

Liu, X. B., Yu, Q. Q., Fujitsuka, T., Liu, B. B., Bi, J., \& Tomohiro, S. (2010). Functional mechanisms of mandatory corporate environmental disclosure: an empirical study in China. Journal of Cleaner Production, 18, 823-832. https://doi.org/10.1016/j.jclepro.2009.12.022 
Li, Z. (2006). A study on relation of corporate social responsibility and corporate value: empirical evidence from Shanghai Securities Exchange. China Industrial Economy,2, 77-85.

Li, H., \& Wang, Q. (1996). Research on the Chinese Work Unit Society. Peter Lang Pub Inc., Frankfurt Main and New York.

Li, W., \& Zhang, R. (2010). Corporate social responsibility, ownership structure, and political interference: Evidence from China. Journal of Business Ethics,96, 631-645. https://doi.org/10.1007/s10551-010-0488-z

Liang, H. L., Zhang, C., \& Wu, D. Y. (2011). Shang ye ying hang she hui ze ren bao gao pi lu ying xiang yin su yan jiu [Social responsibility to commercial banks]. Cai Kuai Tong Xun,2, 67-69.

Lin, L. W. (2008). Corporate social and environmental disclosure in emerging securities markets: China as a case study (Unpublished doctorial dissertation), University of Illinois, Urbana-Champaign.

Lindblom, C. K. (1994). Research methodology: a step-by-step guide for beginners. Longman, Melbourne, Australia.

Lu, Y., \& Abeysekera, I. (2017). What Do Stakeholders Care About? Investigating Corporate Social and Environmental Disclosure in China. Journal of Business Ethics, 144(1), 169-184. https://doi.org/10.1007/s10551-015-2844-5

Luo, Y., \& Wu, D. H. (2010). Shang shi gong si she hui ze ren bao gao ying xiang yin su yan jiu [Determinants of corporate social responsibility]. She Hui Ze Ren Ti Zhi Yan Jiu,159, $18-23$.

Ma, L. F., \& Zhao, Y. (2009). Corporate social disclosure and determinates analysis in listed companies in China. Security Market Guide,3, 3-9.

Mendenhall, W., Reinmuth, J. E., Beaver, R., \& Duhan, D. (1986), Statistics for management and economics. Duxury Press, Boston.

Nie, J. (2009), Research on information disclosure of corporate social responsibility (Unpublished master's dissertation), the University of Finance and Economics of Tianjing, China.

Niu, H. Q. (2009). Empirical study about motivation to disclose the social responsibility report of the listed companies (unpublished master's dissertation), Zhejiang Gongshang University, Zhejiang.

O'Donovan, G. (2002). Environmental disclosures in the annual report: extending the applicability and predictive power of legitimacy theory. Accounting, Auditing and Accountability Journal, 15(3), 344-371. https://doi.org/10.1108/09513570210435870

Oh, W. Y., \& Chang, Y. K. (2011). The effect of ownership structure on corporate social responsibility: empirical evidence from Korea. Journal of Business Ethics, 104, 283-297. https://doi.org/10.1007/s10551-011-0912-z 
Ong, T., Trireksani, T., \& Djajadikerta, H. G. (2016). Hard and soft sustainability disclosures: Australia's resources industry. Accounting Research Journal,29(2), 198-217. https://doi.org/10.1108/ARJ-03-2015-0030

Peng, H. G., (2009). Research on corporate social disclosure in China (Unpublished master's dissertation), Jilin University, Changchun, China.

Wang, J., Qin, S., \& Cui, Y. J. (2010). Problems and prospects of CSR system development in China. International Journal of Business and Management, 5(12), 18-20. https://doi.org/10.5539/ijbm.v5n12p128

Situ, H., Tilt, C., \& Seet, P. S. (2015, November). Corporate Environmental Reporting (CER) in China: A Stakeholder Perspective. In A-CSEAR 2015-Proceedings of the 14th Australasian Centre on Social and Environmental Accounting Research Conference: A-CSEAR 2015 (p. 165). Academic Conferences and publishing limited.

Shenzhen Stock Exchange Corporate Social Disclosure Guideline SZX. (2006). SZX guidelines. Retrieved May, 2011, from the Shenzhen Stock Exchange site: http://www.seze.cn.

Song, L., \& $\mathrm{Zu}$, L. (2009). Determinants of managerial values on corporate social responsibility: evidence from China. Journal of Business Ethics, 88, 105-117. https://doi.org/10.1007/s10551-008-9828-7

Suchman, M. C. (1995). Managing legitimacy: strategic and institutional approaches. Academy of Management Journal, 20(3), 571-610

Taylor, D., \& Shan, Y. G. (2007). What drives the fledging practices of social and environmental reporting by Chinese companies listed in Hong Kong. Accounting and Performance, 13(2), 55-86.

Watts, R. L., \& Zimmerman, J. L. (1978). Toward a positive theory of determination of accounting standards. The Accounting Review, 53(1), 112-134.

Yang, C. F. (2009). Empirical study on the influential factors of social responsibility of Chinese enterprises, The Economists, 69-79.

Yin, G. F., \& Yu, Z. H. (2009). Zhong guo qi ye she hui ze ren bao gao yan jiu [Analysis on China's corporate social responsibility reports], WTO Jing Ji Dao Kan, 104-151

Zhang, J., Djajadikerta, H. G., \& Zhang, Z. (2015). The Perceptions and Challenges of Corporate Sustainability Reporting in China. In A New Paradigm for International Business (pp. 129-150). Springer, Singapore. https://doi.org/10.1007/978-981-287-499-3_7

Zhu, Q., \& Zhang, Q. (2015). Evaluating practices and drivers of corporate social responsibility: The Chinese context. Journal of Cleaner Production, 100, 315-324. https://doi.org/10.1016/j.jclepro.2015.03.053 